\title{
The Impacts of Agricultural Trade on Economic Growth and Environmental Pollution: Evidence from Bangladesh Using ARDL in the Presence of Structural Breaks
}

\author{
Amogh Ghimire ${ }^{1,2} \mathbb{C}^{\text {, Feiting Lin }}{ }^{1,3}$ and Peifen Zhuang ${ }^{1,2, *}$ \\ 1 College of Economics and Management, Fujian Agriculture and Forestry University, Fuzhou 350002, China; \\ amoghimire@yahoo.com (A.G.); $1889 @$ mju.edu.cn (F.L.) \\ 2 The Research Center for the South Pacific Island Countries, Fujian Agriculture and Forestry University, \\ Fuzhou 350002, China \\ 3 School of Economics and Management, Minjiang University, Fuzhou 350108, China \\ * Correspondence: peifenzhuang@fafu.edu.cn; Tel.: +86-130-0388-6368
}

Citation: Ghimire, A.; Lin, F.; Zhuang, P. The Impacts of

Agricultural Trade on Economic Growth and Environmental Pollution: Evidence from Bangladesh Using ARDL in the Presence of Structural Breaks. Sustainability 2021, 13, 8336. https://doi.org/10.3390/su13158336

Academic Editor: Hongmin Qin

Received: 12 May 2021

Accepted: 20 July 2021

Published: 26 July 2021

Publisher's Note: MDPI stays neutral with regard to jurisdictional claims in published maps and institutional affiliations.

Copyright: (c) 2021 by the authors. Licensee MDPI, Basel, Switzerland. This article is an open access article distributed under the terms and conditions of the Creative Commons Attribution (CC BY) license (https:// creativecommons.org/licenses/by/ $4.0 /)$.

\begin{abstract}
Agricultural trade significantly promotes the economic boom in developing countries. Extensive traditional agricultural production methods have increased the pressure on the agricultural environment by expanding agricultural trade, which has attracted the attention of many scholars. This study aims to empirically examine the impacts of agricultural trade on economic growth and agricultural environmental pollution in Bangladesh from 1972 to 2019, using an Auto Regressive Distributed Lag (ARDL) model with a structural break to examine the long-run and short-run determinants of agricultural environmental pollution in Bangladesh. The ARDL bounds analysis methodology showed that it does not support the hypothesis that agricultural trade led to environmental pollution in the long-run. The results suggest a relationship between economic growth, energy, and FDI towards agricultural environmental pollution, indicating a positive long-run relationship. Furthermore, in the short run, agricultural trade indicates positive drivers towards agricultural environmental pollution. Therefore, it is recommended that the enhancement of trade liberalization policies should ensure cleaner technologies and products that could help reduce environmental pollution.
\end{abstract}

Keywords: agricultural trade; economic growth; environmental pollution; ARDL bounds test; Bangladesh

\section{Introduction}

Bangladesh is primarily an agricultural nation and the agriculture sector plays a vital role in driving the economy, accounting for 50 percent of its employment, and with its gross domestic product (GDP) accounting for $20 \%$ of the country's total GDP [1]. Bangladesh has achieved commendable strides in achieving economic growth through self-sufficiency in food production over the past 40 years [2]. Economic growth contributes towards agricultural trade. Subsequently, agricultural inputs such as chemical fertilizers, pesticides, diesel oil, and electricity for irrigation have increased, leading to the increase of carbon emissions in the process of agricultural production, and other corresponding environmental pollution problems have been gradually highlighted. Bangladesh's agriculture sector still faces challenges such as rapid agricultural land shrinkage, low value-added, and lagging technology. The infinite demand for natural resources by trade activities and the limited supply of resources by the ecological environment are essentially contradictory. The solution is for people to link the rapid growth of trade with the situation of environmental pollution. It is considered that the expansion of trade is one of the reasons for ineffectively reducing the environmental pollution in developing countries. What is the relationship between agricultural trade and environmental pollution in Bangladesh? Does economic growth necessarily lead to environmental degradation?

External linkages, trade relations, and foreign investments with the rest of the world are critical for economic growth when an economy is more open or globalized. Energy 
consumption rises due to these trade and investment activities, releasing $\mathrm{CO}_{2}$ and $\mathrm{SO}_{4}$ [3]. Bangladesh continues to be one of the world's most vulnerable countries to the consequences of climate change [4]. Climate change has badly affected Bangladesh by posing a long-term threat to the country's agricultural sector, especially in areas threatened by flood, coastal erosion, and drought [5]. Agriculture in Bangladesh is significantly dependent on weather, and when typhoons strike the country, the whole crop can be wiped in a matter of hours. Climate change presents a significant threat to Bangladesh's agricultural production and puts its food security risk [6]. Bangladesh, as a low-lying nation located on a delta, may anticipate intensified floods, saltwater infiltration, drought, and other natural catastrophes. Simultaneously, the increasing water level in coastal regions is cutting the productivity of several seed varieties long used by its farmers. Bangladesh has 160 million people in 2006, accounting for 2.4 percent of the world's population. In recent years, the impact of globalization on environmental deterioration has been highlighted in the energy and environment sectors literature. Environmental protections are under threat as a result of globalization. Pollution levels rise when a person's income is low. To increase consumption, people must tolerate pollution. Quality of life is concerned with environmental issues only once individuals have reached a certain standard of living. Globalization can link global markets with global warming, which means that as a result of globalization, the market's connection worldwide is also contributing to global warming [3]. Therefore, Bangladesh starts losing 1.75 percent of its arable land per year-higher than its population rise of 1.5 percent. Its agriculture sector is poorly performing and will have to sustain 19 million inhabitants with considerably less land by 2025 . For food security reasons, farmers must deploy advanced and sustainable methods and innovations, such as stress-tolerant seed varieties that endure extended submergence cycles, elevated levels of salinity, and drought conditions. In Bangladesh, the main health impacts of climate change were temperaturerelated illness, food, water, and vector-borne diseases [7]. To ensure long-term food security, productive, sustainable, and environmentally friendly agricultural systems are required. Technology can play a significant role in farming for these challenges, mainly influenced by environmental factors that require better ways to enhance farming $[8,9]$.

International trade encouraged technology transfer and promoted new levels of consumption [10]. International trade is regarded as a tool for sustainable economic growth, as trade makes it possible to generate products and services more economically by shifting the demand for more competitive output [11-13]. Considering the importance of agriculture in Bangladesh's GDP, reducing trade barriers would raise its agricultural export earnings. A net expansion of foreign direct investment and trade openness would generate multiplier effects that would help fuel economic development and minimize poverty $[14,15]$. An export-led growth strategy helps a country's economic success by opening it up to foreign trade; however, blindly pursuing the volume of agricultural trade and ignoring the sustainability of the ecological environment not only causes the exhaustion of resources, but also due to resource constraints, preference for agricultural trade may have a reverse effect-such as unsustainable economic growth. According to Niu et al. (2020), the increasing global population will encourage the trade in agricultural products and the associated land use and greenhouse gas (GHG) emissions. The characteristics of transformation and the relationship between agricultural land and GHG pollution must be understood to achieve successful economic growth strategies [16]. Trade policies are ineffective tools for reducing global emissions, yet a well-functioning international trading framework will aid environmental problems. The response to climate change-related issues will be supported by a well-functioning international trade policy [17]. Therefore, the impact of agricultural trade on economic growth and environmental pollution is essential for the government to formulate relevant policies and an inevitable focus of academic research.

Several studies have been published on the impact of agricultural exports on economic growth in developed nations, including the studies performed by Chandra and Sahoo [18] and Shirazi and Manap [19], which examine the relationship between exports and economic growth and involve Bangladesh but use panel data. This method of analysis, which uses a 
panel data methodology, does not generally rely on any single country but uses combined data from all the countries involved in the research. According to Williamson, these findings do not allow for broad generalizations regarding developing countries, as panel data assumes that all countries in a sample have the same economic system [20]. More precisely, according to Ukpolo [21], the panel study implies that economic circumstances are homogeneous in the countries under review, concealing the reality of individual countries. Our study significantly contributes to the current literature as it is the first analysis that econometrically analyzes the effect of Bangladesh's agricultural trade on its economic growth and environmental pollution. This analysis intends to include details that policymakers can use to help them choose policies that will support Bangladesh's sustainable economic growth and development.

\section{Literature Review}

Several studies have explored the different perspectives on the relationship between economic growth and the environmental pollution that has existed for a long time. The Club of Rome put forward the idea of "Limits to Growth" in the 1970s, which argued that economic growth was unsustainable under natural resources constraints, so we should slow economic growth and protect the environment [22]. Early developments in this field were well documented by Beckerman (1992), who first proposed the concept of "too poor too green," which means that developing countries do not have enough available resources to protect the environment, and that only rich countries have enough resources to develop green technologies to solve environmental problems [23]. Shafik et al. (1994) and Panayotou et al. (1994) found an inverted " $U$ " shaped relationship between income and environmental pollution [24,25].

A considerable body of research has been conducted in exploring the studies on trade openness, and environmental issues have drawn extensive attention from scholars. There are many relevant theories, including the hypothesis of "pollution haven" based on factor endowment theory $[26,27]$. The impact of free trade on the environment is mainly reflected in two aspects: improving the environment through technological effects. Secondly, environmental pollution is aggravated with the expansion of the economic scale. According to Grossman et al. $(1991,1995)$, the environmental effect of agricultural trade can be divided into structure effect, technology effect, and scale effect [28,29]. The pollution caused by the expansion of advantageous industries is more significant than that caused by the reduction of inferior industries. Agricultural products trade will have a negative impact on the country's environment, and the structural effect is negative. Many findings contradicted this concept, prompting a reassessment of this widely held belief that the structural effect will positively affect the scale effect. The expansion of the economic scale will promote the increase of factor input, which will lead to resource consumption and environmental pollution. The available evidence suggests the contrary, that the expansion of economic scale and the increase of a country's per capita income will increase people's demand for a high-quality environment, which is conducive to the transformation and upgrading of the country's industrial structure. A close relationship has been demonstrated among technological effects, free trade conditions, agricultural trade is conducive to the transfer of agricultural technologies. Agricultural environmental pollution is extremely likely to be reduced if a country adopts resource-saving and ecologically friendly agricultural technology. This suggestion is supported by Antweiler et al. (1998), from which the author established a model on the impact of free trade on the environment and then made an empirical analysis on the $\mathrm{CO}_{2}$ data collected by the global environmental monitoring system. The results showed that the net effect of technology and economic scale was positive; that is, free trade was conducive to the improvement of environmental quality [30].

The impact of agricultural trade on the agricultural environment is uncertain in theoretically. In recent years, there has been a surge in interest in investigating ways for examining the relationship between the two relationships. Based on the flowing 
thought of "virtual resources ecological elements", some scholars have studied the virtual cultivated land and virtual ecology implied in grain trade (chemical fertilizer, etc.) for accounting [31,32]. Some scholars use the decomposition method or measurement method to investigate the impact of agricultural trade on the agricultural environment. The three prevailing categories of research to address this issue are: firstly, agricultural trade has a negative impact on the agricultural environment of a country. Its current form can largely be attributed to the work of Dachs et al. (1997) and Barbier (2000), who pointed out that agricultural trade liberalization would exacerbate a country's over-exploitation of natural resources such as forests $[33,34]$. Similar work has also been pursued by Vilas-Gheso et al. (2007), in which structure effect and technology effect had a positive impact on the amount of chemical fertilizer applied by Mexican farmers, while the scale effect was the opposite, and the scale effect was more obvious [35]. Further support is given by Liu Zifei (2014) that more generally asserts that a quantitative analysis of the environmental effects of China's agricultural trade concluded that the structural effect had a positive effect on reducing the concentration of chemical fertilizers, but combined with other effects, agricultural trade would aggravate China's agricultural environmental pollution [36]. These issues have been researched by Chen Wen (2012), who used the cointegration analysis method to analyze the impact of China's agricultural product export trade on the agricultural environment, and the results generally seem to support the positive correlation between them [37]. Secondly, agricultural trade has a positive impact on a country's agricultural environment. A study by Zhang Xiangwen et al. (2012) showed that the scale effect and structure effect of agricultural trade would increase the application amount of chemical fertilizers and pesticides, while the technical effect had the opposite effect. Trade liberalization has the potential to improve the agricultural environment in terms of total utility [38]. Zhou Shudong (2001) pointed out that the import of bulk agricultural products could reduce the application amount of chemical fertilizer in China by simulating the effect of tariff quota on bulk agricultural products [39]. Thirdly, the impact of agricultural trade on the agricultural environment is uncertain $[40,41]$. The impact of agricultural trade on the agricultural environment is inevitably different due to different research data and methods.

The existing studies rarely consider endogeneity, for which the studies of $\mathrm{Li}$ and Qi (2014), Gao and Chen (2011) have reference values [40,41]. Gao and Chen (2014) pointed out that chemical fertilizer film is an important source of agricultural carbon emissions, and endogeneity should be dealt with when examining the performance of agricultural trade, agricultural growth, and carbon emissions [41]. Similarly, Li and Qi (2011) analyzed trade openness, economic growth, and China's environment, they adopted the lag instrumental variable to solve the endogenous problem [40].

Based on the above, this paper attempts to analyze the impacts of agricultural trade on economic growth and environmental pollution in two aspects. First, in the accounting of environmental pollution indicators, the availability and comprehensiveness of data should be considered comprehensively, so the environmental pollution should be measured by greenhouse gas emissions. These indicators represent the present situation of the agricultural environment, and also reflect the intensity of agricultural environmental pollution. Secondly, in terms of research methods, this paper adopts the "Auto Regressive Distributed Lag" (ARDL) model in the presence of structural breaks to analyze the impact and try to check the stability of a long run and short-run equilibrium relationship between environmental pollution, agricultural trade and economic growth in Bangladesh.

The rest of the paper is structured as follows. The model data and econometric methods are illustrated in Section 3. The empirical results and discussion in Section 4. Finally, Section 5 summarizes the study's key conclusions and presents some policy guidelines.

\section{Materials and Methods}

\subsection{Model and Data}

In this study, we refer to the pioneering work of Saboori et al. (2012) [42] and Lacheheb et al. (2015) [43], who applied the idea that using the relationship between envi- 
ronmental degradation by means of economic growth and trade, the standard estimation model can be expressed as follows:

$$
\mathrm{E}=f(Y, T, Z)
$$

where $E$ represents as environmental degradation as a function of economic growth $(Y)$, agricultural trade $(T)$, and a set of control variables $(Z)$. In order to provide a clear interpretation of the coefficients, all variables converted into logarithm forms and plug into an econometric model, and therefore, the estimation model (1) will be:

$$
\ln E_{t}=\alpha_{0}+\alpha_{1}\left(\ln Y_{t}\right)+\alpha_{2}\left(\ln T_{t}\right)+\alpha_{3}\left(\ln Z_{t}\right)+\varepsilon_{t}
$$

$E_{t}$ refers to disturbance term, $l n$ stands as logarithmic form and $t$ represents a time series, which means the elasticity of $Y_{t}, T_{t}$ and $Z_{t}$ respectively.

In Bangladesh, the problem of increasing energy efficiency led to implementing strategies that reduce the excessive uses of energy consumption, ultimately leading to a decline in the economic growth associated with the collapse of farming industries that depend mostly on the combustion of fossil fuels like oil. Moreover, financial developments such as foreign direct investment drive agricultural inputs such as chemical fertilizers, pesticides, diesel oil, and electricity for irrigation increased. Therefore, this study considers energy consumption and foreign direct investment in agriculture as control variables. In econometric theories, the presence of multicollinearity in the model leads to increased standard errors and further affects the hypothetical decision rules criterion. Then we need to eliminate the possibility of the presence of the multicollinearity problem between economic growth, agricultural trade, and other control variables, so we drop all highly correlated variables and remained the rest of other explanatory variables presented as Equation (3). It has been shown in the studies of Chandio et al. [44] and Naseem et al. [45] that the method can be extended to study the impact of economic growth and energy on agriculture environmental pollution.

$$
\ln A E P_{t}=\alpha_{0}+\alpha_{1}\left(\ln G D P_{t}\right)+\alpha_{2}\left(\ln T R O_{t}\right)+\alpha_{3}(\ln E N E R G Y)+\alpha_{4}\left(L N F D I_{t}\right)+\varepsilon_{t}
$$

An overall summary of the data is given in Table 1. This study examines multiple aspects of determinant factors that affect the environmental pollution of Bangladesh, using annual data for over 48 years (1972 to 2019) from the World Bank and FAO. The People's Republic of Bangladesh was established in January 1972, so we begin in 1972. The GDP per capita is an obvious endogenous variable, and the endogeneity problem must be addressed since there is a two-way causal relationship between economic growth and the agricultural environment. Growing demands for the quality of the living environment are constantly increasing, especially as GDP per capita increases. The government and relevant departments will change incentive methods and formulate and implement relevant environmental rules according to economic development changes. Environmental regulations and guidelines that are strictly may have a negative impact on agricultural production, or they may drive the process or technological innovation and have a positive impact on agricultural development. As a result, when the endogeneity problem exists, the OLS of Equation (3) will result in bias. Therefore, a lag period is used to avoid this problem.

\subsection{Methodology}

\subsubsection{Unit Root Test with Structure Breaks}

The researchers stressed the need for time-series data to be stationary for the effectiveness of estimation and forecasting. A unit root test checks if a component in the time series is non-stationary and has a unit root [45]. The null hypothesis is commonly described as the lack of a unit root, and, based on the test used, the alternative hypothesis has been either stationary at the level of trend stationarity or volatile root. Unit root tests may be used to decide whether to first differentiate or regress pattern data on deterministic time functions 
to make the data stationary [46]. In addition, economic and finance theory also implies the presence of long-run equilibrium correlations in non-stationary time series. Stationarity unit root checks to evaluate the stationarity of the variables, the ADF and Phillips-Perron unit root tests were used to decide if none of the variables were assumed to be integrated in the order I (2). Since the bonding method of cointegration testing is invalidated in I (2) situation. The ADF unit test for the existence of unit root of $y_{t}$ (in Equation (4)) at time $t$ for all variables.

$$
\Delta y_{t}=\vartheta_{0}+\vartheta_{1} t+\vartheta_{2} y_{t-1}+\sum_{i=1}^{n} \beta_{i} \Delta y_{t-i}+\varepsilon_{t}
$$

Table 1. Summary of data variables used in the model.

\begin{tabular}{|c|c|c|c|}
\hline Variable & Symbol & Explanation & Source \\
\hline $\begin{array}{l}\text { Agricultural } \\
\text { Environment } \\
\text { Pollution }\end{array}$ & $(\mathrm{AEP})$ & $\begin{array}{l}\text { Agricultural environment pollution refers to all emissions from agricultural } \\
\text { sub-domains (burning of crop residues, burning of savanna, cultivation of } \\
\text { organic soils, crop residues, enteric fermentation, manure applied to soils, } \\
\text { manure management, manure left on pastures, rice cultivation, and synthetic } \\
\text { fertilizers), giving a picture of the contribution to total } \mathrm{GHG} \text { emissions } \\
\text { measured in gigagrams. Non- } \mathrm{CO}_{2} \text { gases such as methane }\left(\mathrm{CH}_{4}\right) \text { and nitrous } \\
\text { oxide }\left(\mathrm{N}_{2} \mathrm{O}\right) \text { are emitted by crop and livestock processing and management } \\
\text { practices, resulting in GHG emissions from agricultural activities. }\end{array}$ & FAO \\
\hline Economic Growth & $(G D P)$ & $\begin{array}{c}\text { Economic growth includes GDP per capita growth. Based on the constant } \\
\text { local currency, the annual percentage rate of GDP per capita growth. The } \\
\text { statistics are in constant } 2010 \text { USD. }\end{array}$ & World Bank \\
\hline $\begin{array}{l}\text { Agricultural Trade } \\
\text { Openness }\end{array}$ & $(T R O)$ & $\begin{array}{l}\text { Trade openness is calculated as the sum of a country's agricultural exports } \\
\text { and agricultural imports as a share of that country's agricultural GDP (\%) }\end{array}$ & FAO \\
\hline Energy & (ENERGY) & $\begin{array}{l}\text { Energy use refers energy use which consists of } \mathrm{CO}_{2}, \mathrm{CH}_{4} \text { and } \mathrm{N}_{2} \mathrm{O} \text { gases are } \\
\text { produced as result of burning fuel and electricity generation in agriculture. }\end{array}$ & FAO \\
\hline $\begin{array}{l}\text { Foreign Direct } \\
\text { Investment }\end{array}$ & $F D I$ & $\begin{array}{l}\text { Foreign direct investment FDI refers to net inflows (\% of GDP). FDI applies } \\
\text { to the net inflows of funds used to obtain a long-term management stake } \\
(10 \% \text { or more in voting stock) in a company that operates in a nation other } \\
\text { than the investors if seen in the balance of payments, which is the number of } \\
\text { equity investments, earnings reinvestment, various short-term capital, and } \\
\text { long-term capital. }\end{array}$ & World Bank \\
\hline
\end{tabular}

The $\Delta y_{t-i}$ signifies the first difference of the variable at $\mathrm{n}$ lags. $\vartheta_{0}, \vartheta_{1}, \vartheta_{2}$ are the coefficients will be estimated. The null hypothesis for unit root is $\mathrm{H}_{0}: \vartheta_{2}=0$, and an alternative hypothesis is $\mathrm{H}_{1}: \vartheta_{2} \neq 0$. The Dickey-Fuller unit root test that allows for a transition in the intercept is often premeditated to validate the probability of structural breaks. As it is over a long time, we will use the structural break unit root test to decide whether the sequence is stationary except in the face of a potential structural break by Enders W and Lee J, 2012 [47].

$$
\Delta y_{t}=f+\alpha_{2} y_{t-1}++\beta_{t}+\theta_{1} D U M_{t}+\sum_{i=1}^{n} d_{i} \Delta y_{t-i}+\varepsilon_{t}
$$

The $\Delta$ denotes the first difference, $\varepsilon_{t}$ is the error term expected to be white noise, $\Delta y_{t-i}$ permits for serial correlation, and $D U M_{t}$ is a dummy variable for a meaningful change at time $t$. In Equation (5), $D U M_{t}=1$ if $t>\mathrm{TA}$ or 0 otherwise. The null hypothesis is that $y_{t}$ is an integrated phenomenon with no structural break, while the opposite hypothesis is that $y_{t}$ is a stationary pattern with a structural break at an uncertain moment [48].

\subsubsection{ARDL, Bounds Testing Approach}

The Johansen multivariate cointegration modeling method has become the standard because of its emphasis on pretests for the order of integration and its ability to respond quickly to mixed orders of integration processes. This approach has notable shortcomings [49]. Thus, when it comes to cointegration and ECMs, our choice for the 
autoregressive distributed lag (ARDL) approach appears reasonable, which is also suggested by Pesaran et al. (2001) as an alternative to Johansen's cointegration test, we also perform a complementary cointegration test. The ARDL method enables ECM-based causal inference and is preferable to other prominent formulations as it circumvents the need for possibly biased unit root pretests and possible problems of mixed integration order [50-52]. Therefore, the evaluation of the nature of long-term relationships would not imply that the variables have the same integration order. For limited tests, this method often generates desirable statistical properties. The long-run ARDL estimate calculations were super consistent but also that traditional asymptotic theory could be used to create a clear conclusion [53-55]. The error correction variant described by Equation (6) of the ARDL model could be represented as:

$$
\begin{aligned}
\Delta \mathrm{AEP}_{t}=\alpha_{0} \quad & \alpha_{1} G D P_{t-1}+\alpha_{2} A E X_{t-1}+\alpha_{3} T_{R O} O_{t-1}+\alpha_{4} \text { ENERGY }_{t-1}+\alpha_{5} F D I_{t-1} \\
& +\alpha_{6} \text { Dummy }_{t}+\sum_{i=1}^{n} \alpha_{7} \Delta A E P_{t-1}+\sum_{i=1}^{n} \alpha_{8} \Delta G D P_{t-1} \sum_{i=1}^{n} \alpha_{9} \Delta A E X_{t-1} \\
& +\sum_{i=1}^{n} \alpha_{10} \Delta T R O_{t-1}+\sum_{i=1}^{n} \alpha_{11} \Delta E N E R G Y_{t-1}+\sum_{i=1}^{n} \alpha_{11} \Delta F D I_{t-1}+\varepsilon_{1 t}
\end{aligned}
$$

The null hypothesis and the alternative hypothesis in all the above equations is as follows:

$$
\begin{gathered}
H_{0}: \alpha_{1}=\alpha_{2}=\alpha_{3}=\alpha_{4}=\alpha_{5}=0 \\
H_{1}: \alpha_{1} \neq \alpha_{2} \neq \alpha_{3} \neq \alpha_{4} \neq \alpha_{5} \neq 0
\end{gathered}
$$

The null hypothesis in the above equations is that there is no long-term reexamination. In the equation, a relationship exists between the variables. The Wald F-test is used for this purpose. It senses the general meaning of the variables lagged values in the equation and provides us with the critical F-statistic and upper and lower values. Proof of cointegration is found when the F statistics above the upper critical point and vice versa. The conclusion is inconclusive in situations where F-statistics are between the upper and lower bound values [54]. Cointegrating equations are estimated using a long-term error, referred to as the error correction term in the error correction model after cointegration between variables is established. It illustrates the speed of transition in long-term factors, which provides an understanding of the partnership's longevity [55]. The Error Correction Model (ECM) representation of the ARDL approach is as follows:

$$
\begin{aligned}
\Delta \mathrm{AEP}_{t}=\alpha_{0}+ & \sum_{i=1}^{n} \alpha_{7} \Delta A E P_{t-1}+\sum_{i=1}^{n} \alpha_{8} \Delta G D P_{t-1} \sum_{i=1}^{n} \alpha_{9} \Delta A E X_{t-1}+\sum_{i=1}^{n} \alpha_{10} \Delta T R O_{t-1} \\
& +\sum_{i=1}^{n} \alpha_{11} \Delta E N E R G Y_{t-1}+\sum_{i=1}^{n} \alpha_{11} \Delta F D I_{t-1}+\alpha_{12} \Delta E C T_{t-1}+\varepsilon_{1 t}
\end{aligned}
$$

After a short-term shock, the essence of the $E C T_{t-1}$ (Equation (7)) is to show the speed of adaptation back to long-term equilibrium. To maintain the model's well-being, we carry out a series of diagnostic tests. The serial relation, functional form, normality, and heteroscedasticity associated with the chosen model were especially explored during this analysis. Stability tests (CUSUMQ and CUSUM) are helpful for checking the stability of the regression coefficients, as described by Pesaran et al. (2001) [53]. The tests are recursively updated and plotted against the breakpoint. The null hypothesis of all regression coefficients presented is stable and cannot be disregarded if the plot is below the $5 \%$ significance mark.

\section{Result and Discussion}

\subsection{Statistical Summaries}

Descriptive statistics of all variables for Bangladesh have been listed in Table 2. The agricultural environmental pollution (AEP) has also shown a positive variation of means 5.09. Significant variations are being observed in economic growth (GDP)for Bangladesh. The maximum value is 3.11 , while the minimum value is 2.51 . The agricultural trade openness (TRO) observations imply few differences in maximum and minimum values 
for Bangladesh. The maximum value is 1.58 , while the minimum value is 0.69 . The lowest number of variations has been observed in ENERGY for Bangladesh. The maximum value is 10.90 , while the minimum value is 7.10 . The significant variations are being observed in the FDI has shown the highest amount of variation for Bangladesh. The maximum value is 9.45, while the minimum value is 0.00 . The positive Kurtosis coefficients indicating flatness for all variables as far as Skewness's matter has positive.

Table 2. Descriptive Statistics.

\begin{tabular}{ccccccccc}
\hline & Mean & Med & Max & Mini & $\begin{array}{c}\text { Std. } \\
\text { Dev. }\end{array}$ & Skewness & Kurtosis & $\begin{array}{c}\text { Jarque- } \\
\text { Bera }\end{array}$ \\
\hline LNAEP & 5.09 & 5.10 & 5.21 & 4.99 & 0.07 & 0.02 & 1.69 & 3.37 \\
LNGDP & 2.72 & 2.67 & 3.11 & 2.51 & 0.17 & 0.75 & 2.37 & 5.29 \\
LNTRO & 1.17 & 1.12 & 1.58 & 0.69 & 0.23 & 0.23 & 2.04 & 2.27 \\
LNENERGY & 9.61 & 9.90 & 10.90 & 7.10 & 1.05 & -0.55 & 2.24 & 3.58 \\
LNFDI & 7.76 & 7.34 & 9.45 & 0.00 & 1.51 & -2.71 & 15.56 & 374.04 \\
\hline
\end{tabular}

Note: Calculated and generated from EViews 10 software.

To choose the appropriate lag order of the relevant variables to utilize the ARDL model. The lag order must be checked since the F-test is more sensitive with lag order. This empirical study utilized many lag order tests in Table 3 such as LR, FPE, AIC, SC, and HQ. Based on the results, the lag length 5 was selected most by (LR, FPE, AIC, and HQ) the lag selection criteria except for (SC), which selects lag length 1 so we choose lag 5.

Table 3. VAR lag order selection.

\begin{tabular}{ccccccc}
\hline Lag & LogL & LR & FPE & AIC & SC & HQ \\
\hline 0 & 102.4044 & NA & $6.66 \times 10^{-9}$ & -4.638306 & -4.431441 & -4.562482 \\
1 & 342.5455 & 411.6704 & $2.39 \times 10^{-13}$ & -14.88312 & $-13.64193 *$ & -14.42817 \\
2 & 363.3245 & 30.67382 & $3.08 \times 10^{-13}$ & -14.68212 & -12.4066 & -13.84805 \\
3 & 390.6573 & 33.84059 & $3.17 \times 10^{-13}$ & -14.7932 & -11.48336 & -13.58001 \\
4 & 417.51 & 26.85273 & $3.88 \times 10^{-13}$ & -14.88143 & -10.53726 & -13.28912 \\
5 & 488.3893 & $54.00327^{*}$ & $7.57 \times 10^{-14} *$ & $-17.06616^{*}$ & -11.68766 & $-15.09472 *$ \\
\hline
\end{tabular}

Note: * indicates the lag order selected by the criterion. LR: sequential modified LR test statistics (each test at 5\% level); FPE: final prediction error; AIC: Akaike information criterion; SC: Schwarz information criterion; HQ: Hannan-Quinn information criterion.

The ADF and the PP unit root test were used to verify and evaluate the order of integration. The effects of the ADF and the PP unit root test in Table 4. Result demonstrates that both ADF and PP unit root test the variables were non-stationary at their stage and stationary at their first differences, becoming integrated to zero (0) and one (1). We observe that, for Bangladesh, the order of integration of the variables may either be a mix of $\mathrm{I}(0)$ and $\mathrm{I}(1)$ or purely $\mathrm{I}(1)$. The ADF unit root test provides a dummy for structure break for mean changes during each structure break and pattern transition. The ADF units of interception and trend were recorded and indicate that all variables are non-stationary at the level, whereas all variables were stationary at the $1 \%$ significance level at the first difference (Tables 4 and 5).

\subsection{ARDL Bounds Test for Co-Integration}

The long-run relationship outcomes are adaptive to the lag length chosen in the model [58]. In Table 6 indicates choosing the optimal lag length in the model, the measured F-statistic. The bound test was conducted to check the long-term association between variables by conducting an F-test to evaluate the coefficients of the shifted variable coefficients. The null hypothesis of no cointegration will be rejected if the calculated F statistic exceeds the upper bound critical value. No cointegration null can be rejected if the estimated F statistic is smaller than the lower limit's critical value $[59,60]$. The conclusion F statistic is between the lower and upper limit essential values for Bangladesh. According 
to Godfrey and Orme (1994), ARDL model residuals are normally distributed and are thus exempt from the issue of serial correlation (lag was used if any correlation was found) and heteroskedasticity use of ARDL White's test done for heteroskedasticity found in data [61]. When the outcomes of the Bayer and Hanck (2013) [62] cointegration test were analyzed, it was discovered that AEP and other variables had a cointegration connection since the estimated Fisher Test statistic values were larger than the critical value for AEP. Consequently, the presence of a long-run connection between these variables was established. All diagnostic tests reveal that there is no problem with normality, serial correlation heteroskedasticity in the model [63].

Table 4. Unit root tests.

\begin{tabular}{|c|c|c|c|c|c|c|c|c|}
\hline & \multicolumn{4}{|c|}{ PP Test } & \multicolumn{4}{|c|}{ ADF Test } \\
\hline & \multicolumn{2}{|c|}{ With Constant } & \multicolumn{2}{|c|}{ With Constant and Trend } & \multicolumn{2}{|c|}{ With Constant } & \multicolumn{2}{|c|}{ With Constant and Trend } \\
\hline & Level & $\Delta$ & Level & $\Delta$ & Level & $\Delta$ & Level & $\Delta$ \\
\hline AEP & $\begin{array}{l}-0.19 \\
(0.93)\end{array}$ & $\begin{array}{l}-7.33 \\
(0) * * *\end{array}$ & $\begin{array}{l}-3.14 \\
(0.10)\end{array}$ & $\begin{array}{l}-7.24 \\
(0) * * *\end{array}$ & $\begin{array}{l}-0.37 \\
(0.90)\end{array}$ & $\begin{array}{l}-7.17 \\
(0) * * *\end{array}$ & $\begin{array}{l}-3.14 \\
(0.10)\end{array}$ & $\begin{array}{l}-7.09 \\
(0)^{* * * *}\end{array}$ \\
\hline GDP & $\begin{array}{c}10.01 \\
(1)\end{array}$ & $\begin{array}{l}-5.95 \\
(0) * * *\end{array}$ & $\begin{array}{c}2.74 \\
(1)\end{array}$ & $\begin{array}{l}-9.79 \\
(0)^{* * *}\end{array}$ & $\begin{array}{c}5.73 \\
(1)\end{array}$ & -0.740 .82 & $\begin{array}{l}1.24 \\
(0.99)\end{array}$ & $\begin{array}{c}-9.7 \\
(0)^{* * *}\end{array}$ \\
\hline TRO & $\begin{array}{l}-1.89 \\
(0.33)\end{array}$ & $\begin{array}{l}-12.41 \\
(0)^{* * * *}\end{array}$ & $\begin{array}{c}-4.09 \\
(0.01)^{* *}\end{array}$ & $\begin{array}{l}-12.41 \\
(0) * * *\end{array}$ & $\begin{array}{l}-1.89 \\
(0.33)\end{array}$ & $\begin{array}{c}-11.39 \\
(0) * * *\end{array}$ & $\begin{array}{c}-4.09 \\
(0.01) * *\end{array}$ & $\begin{array}{l}-11.31 \\
(0)^{* * *}\end{array}$ \\
\hline ENERGY & $\begin{array}{c}-3.97 \\
(0.00)^{* * *}\end{array}$ & $\begin{array}{c}-6.76 \\
(0.00)^{* * *}\end{array}$ & $\begin{array}{l}-3.29 \\
(0.08) *\end{array}$ & $\begin{array}{c}-8.71 \\
(0.00)^{* * * *}\end{array}$ & $\begin{array}{c}-3.07 \\
(0.03) * *\end{array}$ & $\begin{array}{c}-6.71 \\
(0.00)^{* * *}\end{array}$ & $\begin{array}{l}-3.30 \\
(0.08)\end{array}$ & $\begin{array}{c}-7.97 \\
(0.00)^{* * *}\end{array}$ \\
\hline FDI & $\begin{array}{c}-3.85 \\
(0.00)^{* * *}\end{array}$ & $\begin{array}{c}-35.40 \\
(0.00)^{* * *}\end{array}$ & $\begin{array}{l}-7.24 \\
(0)^{* * *}\end{array}$ & $\begin{array}{c}-35.98 \\
(0) * * *\end{array}$ & $\begin{array}{l}-0.38 \\
(0.90)\end{array}$ & $\begin{array}{c}-5.20 \\
(0.00)^{* * *}\end{array}$ & $\begin{array}{l}-6.96 \\
(0)^{* * *}\end{array}$ & $\begin{array}{c}-5.22 \\
(0.00)^{* * *}\end{array}$ \\
\hline & \multicolumn{8}{|c|}{ Ng-Perron test statistics } \\
\hline & \multicolumn{4}{|c|}{ Level } & \multicolumn{4}{|c|}{$\Delta$} \\
\hline & MZa & MZt & MSB & MPT & MZa & MZt & MSB & MPT \\
\hline AEP & 1.24 & 0.98 & $0.78^{* * *}$ & 47.74 & $-22.39 * * *$ & $-3.33^{* * *}$ & $0.14^{* * *}$ & $1.12^{* * *}$ \\
\hline GDP & $-36.62 * * *$ & $-4.08^{* * *}$ & $0.11^{* * *}$ & $1.21^{* * *}$ & -4.96 & -1.38 & 0.27 & 5.37 \\
\hline TRO & -4.59 & -1.35 & $0.29^{* * *}$ & 5.64 & -0.37 & -0.31 & 0.82 & 36.84 \\
\hline ENERGY & 0.93 & 1.15 & 1.25 & 102.68 & $-22.34 * * *$ & $-3.32 * * *$ & $0.15^{* * *}$ & $1.19^{* * *}$ \\
\hline FDI & $-17.28^{* * *}$ & $-2.88^{* * *}$ & $0.16^{* * *}$ & $1.63^{* * *}$ & -0.64 & -0.56 & 0.87 & 37.65 \\
\hline
\end{tabular}

Note: $\Delta$ represents the first difference, ${ }^{* * *},{ }^{* *}$ and ${ }^{*}$ indicate statistical significance at $1 \%, 5 \%$, and $10 \%$ levels, respectively. ${ }^{*}$ MacKinnon (1996) one-sided $p$-values [56].

Table 5. ADF test for structural breaks.

\begin{tabular}{ccccc}
\hline AEP & Level/ $\boldsymbol{\Delta}$ & t-Statistic & Significance & Break Date \\
\hline Augmented Dickey-Fuller test statistic & Level & -1.739251 & NO & 1988 \\
& $\Delta$ & -11.06333 & $* * *$ & 1980 \\
\hline Perron Unit Root Test & Intercept & -6.300607 & $* * *$ & 1979 \\
& Both & -6.710062 & $* * *$ & 1979 \\
& Trend & -3.710642 & NO & 1984 \\
\hline
\end{tabular}

Note: $\Delta$ represents the first difference, ${ }^{* * *}$ indicate statistical significance at $1 \%$ levels. ADF is an augmented dicky fuller. * Vogelsang (1997) asymptotic one-sided $p$-values [57].

\subsection{Long-Run and Short-Run Elasticities}

In Table 7, it reveals that all variables were the significant factor for $A E P$ in Bangladesh. The effect of economic growth (GDP) on $A E P$ was significant at a $1 \%$ level of significance. The coefficient $(0.03)$ of economic growth indicates a $1 \%$ increase in economic growth that increases the $A E P$ by $0.03 \%$ in the long run. The result is similar to the result of Boamah et al., 2018 [64], Rahman et al., 2020 [65]. However, in contrast to the result of Naseem et al., 2021 [45] and Chandio et al., 2019 [44]. According to the Kahia et al. (2021) study, greenhouse gas emissions rise due to economic growth, and a continual rise in $\mathrm{CO}_{2}$ emissions will slow economic growth. In a nutshell, greenhouse gas might be reduced 
at the expense of economic growth or by promoting the use of efficient technologies and importing efficient technologies from industrialized nations [66].

Table 6. Estimated ARDL test to co-integration.

\begin{tabular}{|c|c|c|}
\hline Test Statistics & Test Statistics Value & No. of Regressors (K) \\
\hline F-Statistics (AEP) & 334.22 & 5 \\
\hline Lags Levels & $(4,0,3,0,2,1)$ & \\
\hline Cointegration & Yes & \\
\hline F-Statistics & $11.59^{* * *}$ & \\
\hline Lower Bound I (0) & Upper Bound I (1) & Significance Level \\
\hline 2.26 & 3.35 & $*$ \\
\hline 2.62 & 3.79 & $* *$ \\
\hline 3.41 & 4.68 & $* * *$ \\
\hline \multicolumn{3}{|c|}{ Bayer Hanck Test } \\
\hline EG-JOH & EG-JOH-BO-BDM & Cointegration \\
\hline $55.32 * * *$ & $66.11^{* * *}$ & Yes \\
\hline Critical Values & Critical Values & Significance Level \\
\hline 8.30 & 15.93 & * \\
\hline 10.58 & 20.14 & $* *$ \\
\hline 15.84 & 30.77 & $* * *$ \\
\hline \multicolumn{3}{|c|}{ Diagnostic Tests } \\
\hline & F-statistics & $p$-value \\
\hline Normality test (Jarque-Bera) & 3.42 & 0.18 \\
\hline Breusch-Pagan (Heteroskedasticity test) & 0.66 & 0.80 \\
\hline Breusch-Godfrey (LM test) serial correlation & 1.43 & 0.25 \\
\hline
\end{tabular}

Note: ${ }^{* * *},{ }^{* *}$ and ${ }^{*}$ indicate statistical significance at $1 \%, 5 \%$ and $10 \%$ level, respectively.

Table 7. Estimated long-run coefficients.

\begin{tabular}{ccccc}
\hline & Coefficient & Std. Error & $\boldsymbol{t}$-Statistic & Prob. \\
\hline C & 2.32 & 0.49 & 4.72 & $* * *$ \\
LNAEP & -0.55 & 0.12 & -4.71 & $* * *$ \\
LNGDP & 0.03 & 0.01 & 3.86 & $* * *$ \\
LNTRO & -0.07 & 0.02 & -3.81 & $* * *$ \\
LNENERGY & 0.02 & 0.01 & 3.72 & $* * *$ \\
LNFDI & 0.02 & 0.00 & 4.06 & $* * *$ \\
DUMAEP & 0.09 & 0.04 & 2.17 & $* *$ \\
\hline
\end{tabular}

Note: ${ }^{* * *},{ }^{* *}$ and ${ }^{*}$ indicate statistical significance at $1 \%, 5 \%$, and $10 \%$ level, respectively.

The effect of agricultural trade openness (TRO) on $A E P$ was significant at a $1 \%$ level of significance. The coefficient $(-0.07)$ of TRO shows that a $1 \%$ increase in economic growth leads to an $0.07 \%$ diminish in AEP in the long run. According to Tekce and Deniz, (2016), agricultural trade is among the most vulnerable areas of the economy that climate change is projected to disrupt, particularly in developing countries [67]. Evidence from Tian et al., (2018) cohort studies concluded that economic growth and international trade have a clear impact on the environment and its resources. On the other hand, resources and the environment have a significant impact on economic systems. Climate change could alter the regional distribution of economic patterns. Some countries' agricultural production will improve, while other countries' agricultural production will suffer. Apart from this, resource depletion and environmental transformations will erode one country's comparative advantage and upset global trade and economic patterns [68]. Our result is consistent with Nosheen et al., (2021) findings, which suggest that trade liberalization has a direct and significant impact on $\mathrm{CO}_{2}$ emissions. Trade liberalization has a variety of effects on the environment. It has the potential to both increase and decreases pollution 
levels. Trade has a direct impact on the environment due to the scale effect. The invisible hand of trade liberalization is meant to enhance the size of production and specialization. As a result, in the case of free trade, greater integration allows manufacturing activities to expand at a bigger scale, lowering environmental quality. Free trade, on the other hand, is meant to enhance the inflow of efficient and eco-friendly technology. Improved and effective technologies are meant to be resource efficient and have a lower pollution effect [69].

Energy was another significant factor of AEP added in Bangladesh. At a 1\% level of significance, the effect of ENERGY ofon AEP is positive. The coefficient (0.02) of ENERGY indicates that a $1 \%$ increase in ENERGY increases the $A E P$ by $0.02 \%$ in the long run. The economic theory supports the relationship between GHG emissions and energy demand. Fossil fuels often impair energy efficiency and degrade the environment in developing countries [70]. To operate heavy farming machinery, process foods, freeze goods during transportation, make packaging materials, and manufacture and distribute chemical inputs, including fertilizers and insecticides, large volumes of fossil fuel are required. Wood et al.'s (2018) study concerns its timeliness, considering the current Bangladesh government's economic diversification strategy, which stresses the promotion of high value-added crops and ready-made goods (RMG). Value-added crops and RMG had the fastest economic growth in terms of environmental footprint [71]. Rapid economic expansion is grounded in the early stages by huge energy consumption, which would be accompanied by large volumes of environmental pollution. However, once economic growth reaches a particular level, environmental regulation trends to become more stringent, taking into account the greenhouse effect's implications [72].

Foreign direct investment (FDI) was the significant factor of the $A E P$ in Bangladesh. The effect of $F D I$ on the $A E P$ is a significant $1 \%$ level of significance. The coefficient $(0.02)$ of FDI shows that a $1 \%$ increase in FDI leads to an over $0.02 \%$ increase in the $A E P$ in the long run. Agricultural export and trade openness were the significant factors of foreign direct investment (FDI). In developing countries, greenhouse gas emissions relationship to FDI inflows imply that FDI has been attracted by the lower environmental standard [73].

In Table 8 , for Bangladesh, CointEq $(-1)^{*}(-0.55)$ was significant at $1 \%$ level for AEP. An immensely significant negative sign of the ECM strengthens the long-run relationship among the variables. The speed of adjustment from the previous year's disequilibrium in economic growth to the current year's equilibrium is $55 \%$.

Table 8. Error correction model of ARDL.

\begin{tabular}{ccccc}
\hline ECM & Coefficient & Std. Error & t-Statistic & Prob. \\
\hline C & 2.32 & 0.49 & 4.72 & $* * *$ \\
D(LNAEP) & 0.27 & 0.07 & 3.99 & $* * *$ \\
D(LNTRO) & 0.03 & 0.01 & 3.50 & $* * *$ \\
D(LNFDI) & -0.02 & 0.00 & -5.90 & $* * *$ \\
CointEq(-1)* & -0.55 & 0.06 & -9.10 & $* * *$ \\
\hline
\end{tabular}

Note: ECM, error correction model ${ }^{* * *}$ indicate statistical significance at $1 \%$.

\subsection{Robustness Analysis}

The research further uses the cumulative sum of recursive residuals (CUSUM) and cumulative sum of recursive residual squares (CUSUMQ) after the empirical estimates to evaluate model stability. The plots for the first four equations were calculated in this analysis for the (CUSUM) and (CUSUMQ) provided in Figure 1. It can be concluded based on the plots that the approximate ARDL equations are stable as the CUSUM and CUSUMQ lines do not cross the boundaries at the statistical significance level of $5 \%$. The null hypothesis notes that the ECM coefficients were constant and should not be discarded if the plots lie beyond the 5\% significance level range. The long and short-run parameters were also stabilized utilizing CUSUM and CUSUMQ stability tests. The graphs of both the CUSUM and CUSUMQ tests show that all values were inside the critical limits at 
a significance level of $5 \%$, indicating that the long-run and short-run parameters were stable $[74,75]$.

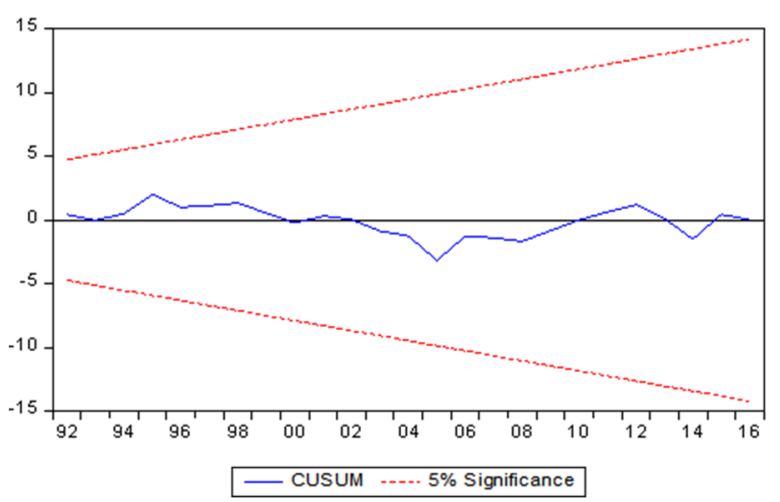

(a)

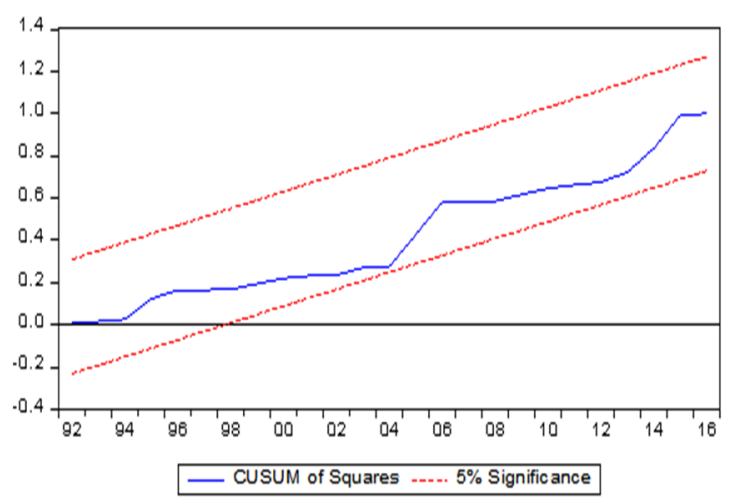

(b)

Figure 1. CUSUM and CUSUMQ test listed as: (a) CUSUM test; (b) CUSUMQ test.

\section{Conclusions and Recommendations}

Economic growth accomplished at the expense of environmental well-being is unlikely to be sustained eventually. Environmental welfare goals are an accepted result of economic development strategies, which attempt to both improve the economy and reduce pollution. Considering these few studies exist in Bangladesh, as in many other developing countries, that corroborate or refute the agricultural trade openness led environmental pollution with relation to agricultural environmental pollution and the variables that drive agricultural environmental pollution, which is crucial for policymakers. The data includes the period 1972 to 2019 to conduct time series econometric analyses that are resilient to the structure break in the data. The ARDL model calculation statistically does not validate the agricultural trade openness-led environmental pollution hypothesis in Bangladesh. Agricultural environment pollution was observed as positively impacted by the increase of economic growth, energy, and FDI in the long run. However, in the short run, agricultural environment pollution was positively impacted by the agricultural trade oneness.

The findings of this study have some significant policy consequences. To begin with, since the economic growth eventually compensates for the negative environmental effects that occur during the early stages of growth, the economies of Bangladesh must accelerate their respective growth rates. However, to protect environmental attributes, development plans should be more matched with environmental welfare policies. The result suggests that the connection between GDP per capita and agricultural environmental pollution shows that the rapid economic growth means that additional increases in GDP per capita will only be connected with increases in agricultural environmental pollution. In order to meet international commitments to global warming mitigation, the study recommends developing and implementing the Low Carbon Development Strategy, which integrates development and climate change mitigation strategies as elaborated in the United Nations Framework Convention on Climate Change. Technology advancements and legislation that lead to proper resource pricing should be the focus of such solutions. Regarding agricultural environmental pollution determinants, the findings show that agricultural trade openness has a beneficial impact on agricultural environmental pollution, and the agricultural trade openness led environmental pollution hypothesis for agricultural environmental pollution does not apply in Bangladesh. Based on the result, we advocate for increased agricultural trade openness policies that promote the adoption of cleaner technology and goods. In this regard, trade barriers that stifle Bangladesh markets should be removed, as greater foreign trade access is thought to accelerate the adoption of new technology options for Bangladesh.

Furthermore, foreign direct investment in agriculture should be extended in order to reduce the cost of production and to purchase environment-friendly new technology. 
The lower production price is likely to increase energy production more efficiently, resulting in lower greenhouse gas emissions and increased economic growth in Bangladesh. Moreover, energy consumption was shown to have a positive long-term influence on agricultural environmental pollution, indicating that investments in cleaner energy alternatives such as biogas, solar, and energy efficiency programs might help reduce agricultural environmental pollution.

This research, however, still offers preliminary scientific data, and there are still some limitations. To begin with, in this study, we used overall agricultural GHG as agricultural environment pollution. Ultimately, it will be helpful to explore the complex causal association between particular emissions (carbon dioxide, methane, and others) and the agriculture trade and economic growth nexus in future studies using individual emissions in our model. Second, other industry's trade was not included in this study aside from agriculture trade. As a result, in a future study of emissions and economic growth, we will show that the linkage between agricultural trade and other sectors will be beneficial for policymakers in devising practical and tailored strategies to mitigate the global warming impact.

Author Contributions: Conceptualization, A.G. and P.Z.; methodology, A.G. and P.Z.; software, A.G. and F.L.; validation, formal analysis, A.G. and P.Z.; investigation, resources, A.G. and P.Z.; data curation, A.G. and F.L; writing—original draft preparation, A.G. and P.Z.; writing—review and editing, A.G. and F.L.; supervision, P.Z. All authors have read and agreed to the published version of the manuscript.

Funding: This research was funded by Ministry of Education, The Implementation Approaches of Belt and Road Initiative in the Pacific Island Country Region.

Institutional Review Board Statement: Not applicable.

Informed Consent Statement: Not applicable.

Data Availability Statement: Publicly available datasets were analyzed in this study. Datasets used have been addressed in the Table 1.

Conflicts of Interest: The authors declare no conflict of interest.

\section{References}

1. Raihan, S. Economic Reforms and Agriculture In Bangladesh: Assessment of Impacts Using Economy-Wide Simulation Models. MPRA Paper No. 37886 2011, 1-55.

2. Roy, A.; Haider, M.Z. Stern Review on the Economics of Climate Change: Implications for Bangladesh. Int. J. Clim. Chang. Strateg. Manag. 2019, 11, 100-117. [CrossRef]

3. Ahad, M.; Khan, W. Does Globalization Impede Environmental Quality in Bangladesh? The Role of Real Economic Activities and Energy Use. Bull. Energy Econ. 2016, 4, 258-279.

4. Ferdushi, K.F.; Ismail, M.T.; Kamil, A.A. Perceptions, Knowledge and Adaptation about Climate Change: A Study on Farmers of Haor Areas after a Flash Flood in Bangladesh. Climate 2019, 7, 85. [CrossRef]

5. Delaporte, I.; Maurel, M. Adaptation to Climate Change in Bangladesh. Clim. Policy 2018, 18, 49-62. [CrossRef]

6. Ahmed, Z.; Guha, G.S.; Shew, A.M.; Alam, G.M.M. Climate Change Risk Perceptions and Agricultural Adaptation Strategies in Vulnerable Riverine Char Islands of Bangladesh. Land Use Policy 2021, 103. [CrossRef]

7. Hasib, E.; Chathoth, P. Health Impact of Climate Change in Bangladesh: A Summary. Curr. Urban Stud. 2016, 04, 1-8. [CrossRef]

8. Malik, A.W.; Rahman, A.U.; Qayyum, T.; Ravana, S.D. Leveraging Fog Computing for Sustainable Smart Farming Using Distributed Simulation. IEEE Internet Things J. 2020, 7, 3300-3309. [CrossRef]

9. Gurnule, P.V. Economical Smart Agriculture Monitoring System. Int. J. Recent Technol. Eng. 2019, 8, 3669-3671. [CrossRef]

10. Sharma, C. Exporting, Access of Foreign Technology, and Firms' Performance: Searching the Link in Indian Manufacturing. $Q$. Rev. Econ. Financ. 2018, 68, 46-62. [CrossRef]

11. Abdullahi, A.O.; Safiyanu, S.S.; Soja, T. International Trade And Economic Growth: An Empirical Analysis Of West Africa. J. Econ. Financ. 2016, 7, 12-15.

12. Purnama, P.D.; Yao, M.H. The Relationship between International Trade and Economic Growth. Int. J. Appl. Bus. Res. 2019, 1, 112-123. [CrossRef]

13. Rahman, M.M.; Shahbaz, M.; Farooq, A. Financial Development, International Trade, and Economic Growth in Australia: New Evidence From Multivariate Framework Analysis. J. Asia Pac. Bus. 2015, 16, 21-43. [CrossRef] 
14. Osabohien, R.; Akinpelumi, D.; Matthew, O.; Okafor, V.; Iku, E.; Olawande, T.; Okorie, U. Agricultural Exports and Economic Growth in Nigeria: An Econometric Analysis. IOP Conf. Ser. Earth Environ. Sci. 2019, 331. [CrossRef]

15. Kalaitzi, A.S.; Cleeve, E. Export-Led Growth in the UAE: Multivariate Causality between Primary Exports, Manufactured Exports and Economic Growth. Eurasian Bus. Rev. 2018, 8, 341-365. [CrossRef]

16. Niu, B.; Peng, S.; Li, C.; Liang, Q.; Li, X.; Wang, Z. Nexus of Embodied Land Use and Greenhouse Gas Emissions in Global Agricultural Trade: A Quasi-Input-Output Analysis. J. Clean. Prod. 2020, 267, 122067. [CrossRef]

17. Huang, H.; von Lampe, M.; van Tongeren, F. Climate Change and Trade in Agriculture. Food Policy 2011, 36. [CrossRef]

18. Parida, P.C.; Sahoo, P. Export-Led Growth in South Asia: A Panel Cointegration Analysis. Int. Econ. J. 2007, 21, 155-175. [CrossRef]

19. Shirazi, N.S.; Manap, T.A.A. Export-led Growth Hypothesis: Further Econometric Evidence from South Asia. Dev. Econ. 2005, 43, 472-488. [CrossRef]

20. Williamson, R.B. The Role of Exports and Foreign Capital in Latin American Economic Growth. South. Econ. J. 1978, 45. [CrossRef]

21. Ukpolo, V. Export Composition and Growth of Selected Low-Income African Countries: Evidence from Time-Series Data. Appl. Econo. 1994, 26, 445-449. [CrossRef]

22. Martino, J.P. The Limits to Growth: A Report for the Club of Rome's Project on the Predicament of Mankind. Technol. Forecast. Soc. Chang. 1973, 4, 323-332. [CrossRef]

23. Beckerman, W. Economic Growth and the Environment: Whose Growth? Whose Environment? World Development. 1992, 20, 481-496. [CrossRef]

24. Shafik, N. Economic Development and Environmental Quality: An Econometric Analysis. Oxf. Econ. Pap. 1994, 46, 757-773. [CrossRef]

25. Panayotou, T. Empirical Tests and Policy Analysis of Environmental Degradation at Different Stages of Economic Development. Pac. Asian J. Energy 1994, 4, 23-42.

26. Walter, I.; Ugelow, J.L. Environmental Policies in Developing Countries. Ambio 1979, 8, 102-109. [CrossRef]

27. Copeland, B.R.; Taylor, M.S. Trade, Growth, and the Environment. J. Econ. Lit. 2004, 42, 7-71. [CrossRef]

28. Grossman, G.M.; Krueger, A.B. Economic Growth and the Environment. Q. J. Econ. 1995, 110, 353-377. [CrossRef]

29. Grossman, G.; Krueger, A. Environmental Impacts of a North American Free Trade Agreement. Natl. Bur. Econ. Res. 1991. [CrossRef]

30. Antweiler, W.; Copeland, B.R.; Taylor, M.S. Is Free Trade Good for the Environment? Am. Econ. Rev. 2001, 91, 877-908. [CrossRef]

31. Lun, W.; Guo, X. The Impact of Agricultural Trade Liberalization on China's Environment and Countermeasures. Chin. Rural Econ. 2002, 1, 46-51.

32. Sun, C.; Tang, W.; Zou, W. Analysis of Virtual Resource Ecological Factors in China's Grain Trade. Resources Science. 2012, 3, 589-597.

33. López, R. Environmental Externalities in Traditional Agriculture and the Impact of Trade Liberalization: The Case of Ghana. J. Dev. Econ. 1997, 53, 17-39. [CrossRef]

34. Barbier, E.B. Links between Economic Liberalization and Rural Resource Degradation in the Developing Regions. Agric. Econ. 2000, 23, 299-310. [CrossRef]

35. Vilas-Ghiso, S.J.; Liverman, D.M. Scale, Technique and Composition Effects in the Mexican Agricultural Sector: The Influence of NAFTA and the Institutional Environment. Int. Environ. Agreem. Polit. Law Econ. 2007, 7, 137-169. [CrossRef]

36. Liu, Z. An Empirical Analysis of the Environmental Effects of China's Agricultural Products Trade. Exploration of Economic Problems. 2014, 12, 110-117.

37. Wen, C.H.E.N. Empirical Study on the Relationship between Agricultural Export Trade and Environmental Pollution in China. J. Fujian Agric. For. Univ. 2012, 15, 31-35.

38. Zhang, X.; Huang, J. Analysis on the Environmental Effects of Agricultural Trade Liberalization in China. J. Agric. Econ. 2012, 6, 85-89.

39. Shudong, Z. The Impact of Import of Agricultural Products on Social Economy and Environment: A Case Study of Jiangsu Province. J. Nanjing Agric. Univ. 2001, 24, 89-92.

40. Li, K.; Qi, S. The Relationship between Trade Openness, Economic Growth and Carbon Dioxide Emissions in China. Econ. Res. J. 2011, 11, 60-72.

41. Gao, M.; Chen, Q. Trade Openness, Economic Growth, Human Capital and Carbon Emission Performance: Evidence from China's Agriculture. Agrotech. Econ. 2014, 11, 101-110.

42. Saboori, B.; Sulaiman, J.B.; Mohd, S. An Empirical Analysis of the Environmental Kuznets Curve for $\mathrm{CO}_{2}$ Emissions in Indonesia: The Role of Energy Consumption and Foreign Trade. Int. J. Econ. Financ. 2012, 4. [CrossRef]

43. Lacheheb, M.; Rahim, A.S.A.; Sirag, A. Economic Growth and Carbon Dioxide Emissions: Investigating the Environmental Kuznets Curve Hypothesis in Algeria. Int. J. Energy Econ. Policy 2015, 5, 1125-1132.

44. Chandio, A.A.; Jiang, Y.; Rauf, A.; Mirani, A.A.; Shar, R.U.; Ahmad, F.; Shehzad, K. Does Energy-Growth and Environment Quality Matter for Agriculture Sector in Pakistan or Not? An Application of Cointegration Approach. Energies 2019, 12, 1879. [CrossRef]

45. Naseem, S.; Ji, T.G.; Kashif, U.; Arshad, M.Z. Causal Analysis of the Dynamic Link between Energy Growth and Environmental Quality for Agriculture Sector: A Piece of Evidence from India. Environ. Dev. Sustain. 2021, 23, 7913-7930. [CrossRef] 
46. Phillips, P.C.B.; Perron, P. Testing for a Unit Root in Time Series Regression. Biometrika 1988, 75, 335-346. [CrossRef]

47. Kwiatkowski, D.; Phillips, P.C.B.; Schmidt, P.; Shin, Y. Testing the Null Hypothesis of Stationarity against the Alternative of a Unit Root. How Sure Are We That Economic Time Series Have a Unit Root? J. Econ. 1992, 54, 159-178. [CrossRef]

48. Enders, W.; Lee, J. A Unit Root Test Using a Fourier Series to Approximate Smooth Breaks. Oxf. Bull. Econ. Stat. 2012, 74, 574-599. [CrossRef]

49. Furuoka, F. Exports and Economic Growth in Sub-Saharan Africa: New Insights from Innovative Econometric Methods. J. Int. Trade Econ. Dev. 2018, 27, 830-855. [CrossRef]

50. Johansen, S. Statistical Analysis of Cointegration Vectors. J. Econ. Dyn. Control 1988, 12, 231-254. [CrossRef]

51. Shahbaz, M.; Tiwari, A.K.; Nasir, M. The Effects of Financial Development, Economic Growth, Coal Consumption and Trade Openness on $\mathrm{CO}_{2}$ Emissions in South Africa. Energy Policy 2013, 61, 1452-1459. [CrossRef]

52. Farhani, S.; Ozturk, I. Causal Relationship between $\mathrm{CO}_{2}$ Emissions, Real GDP, Energy Consumption, Financial Development, Trade Openness, and Urbanization in Tunisia. Environ. Sci. Pollut. Res. 2015, 22, 15663-15676. [CrossRef]

53. Bölük, G.; Mert, M. The Renewable Energy, Growth and Environmental Kuznets Curve in Turkey: An ARDL Approach. Renew. Sustain. Energy Rev. 2015, 52, 587-595. [CrossRef]

54. Pesaran, M.H.; Shin, Y.; Smith, R. Testing for the Existence of a Long-Run Relationship. J. Appl. Econom. 2001, 16, 289-326. [CrossRef]

55. Narayan, P.K.; Narayan, S. Carbon Dioxide Emissions and Economic Growth: Panel Data Evidence from Developing Countries. Energy Policy 2010, 38, 661-666. [CrossRef]

56. Khuong, N.V.; Shabbir, M.S.; Sial, M.S.; Khanh, T.H.T. Does Informal Economy Impede Economic Growth? Evidence from an Emerging Economy. J. Sustain. Financ. Invest. 2021, 11, 103-122. [CrossRef]

57. Mosconi, R.; Paruolo, P. Identification Conditions in Simultaneous Systems of Cointegrating Equations with Integrated Variables of Higher Order. J. Econom. 2017, 198, 271-276. [CrossRef]

58. Mackinnon, J.G. Numerical Distribution Functions for Unit Root and Cointegration Tests. J. Appl. Econom. 1996, 11, 601-618. [CrossRef]

59. Vogelsang, T.J. Wald-Type Tests for Detecting Breaks in the Trend Function of a Dynamic Time Series. Econom. Theory 1997, 13, 818-849. [CrossRef]

60. Bahmani-Oskooee, M.; Bohl, M.T. German Monetary Unification and the Stability of the German M3 Money Demand Function. Econ. Lett. 2000, 66, 203-208. [CrossRef]

61. Godfrey, L.G.; Orme, C.D. The Sensitivity of Some General Checks to Omitted Variables in the Linear Model. Int. Econ. Rev. 1994, 35. [CrossRef]

62. Bayer, C.; Hanck, C. Combining Non-Cointegration Tests. J. Time Ser. Anal. 2013, 34, 83-95. [CrossRef]

63. Hdom, H.A.D.; Fuinhas, J.A. Energy Production and Trade Openness: Assessing Economic Growth, $\mathrm{CO}_{2}$ Emissions and the Applicability of the Cointegration Analysis. Energy Strategy Rev. 2020, 30. [CrossRef]

64. Boamah, K.B.; Du, J.; Boamah, A.J.; Appiah, K. A Study on the Causal Effect of Urban Population Growth and International Trade on Environmental Pollution: Evidence from China. Environ. Sci. Pollut. Res. 2018, 25, 5862-5874. [CrossRef] [PubMed]

65. Rahman, M.M.; Saidi, K.; Mbarek, M.B. Economic Growth in South Asia: The Role of $\mathrm{CO}_{2}$ Emissions, Population Density and Trade Openness. Heliyon 2020, 6. [CrossRef] [PubMed]

66. Kahia, M.; Omri, A.; Jarraya, B. Does Green Energy Complement Economic Growth for Achieving Environmental Sustainability? Evidence from Saudi Arabia. Sustainability 2021, 13, 1264. [CrossRef]

67. Tekce, M.; Deniz, P. The Impacts of Climate Change on Agricultural Trade in the MENA Region. Res. World Econ. 2016, 7. [CrossRef]

68. Tian, X.; Geng, Y.; Sarkis, J.; Zhong, S. Trends and Features of Embodied Flows Associated with International Trade Based on Bibliometric Analysis. Resour. Conserv. Recycl. 2018, 131, 148-157. [CrossRef]

69. Nosheen, M.; Iqbal, J.; Khan, H.U. Analyzing the Linkage among $\mathrm{CO}_{2}$ Emissions, Economic Growth, Tourism, and Energy Consumption in the Asian Economies. Environ. Sci. Pollut. Res. 2021, 28, 16707-16719. [CrossRef]

70. Simionescu, M.; Păuna, C.B.; Niculescu, M.-D.V. The Relationship between Economic Growth and Pollution in Some New European Union Member States: A Dynamic Panel ARDL Approach. Energies 2021, 14, 2363. [CrossRef]

71. Wood, R.; Stadler, K.; Simas, M.; Bulavskaya, T.; Giljum, S.; Lutter, S.; Tukker, A. Growth in Environmental Footprints and Environmental Impacts Embodied in Trade: Resource Efficiency Indicators from EXIOBASE3. J. Ind. Ecol. 2018, 22, 553-564. [CrossRef]

72. Dong, J.; Dou, Y.; Jiang, Q.; Zhao, J. How Does Industrial Structure Upgrading Affect the Global Greenhouse Effect? Evidence From RCEP and Non-RCEP Countries. Front. Energy Res. 2021, 9. [CrossRef]

73. Wu, L.; Wang, H.; Zhu, D.; Wang, H.; Zhu, D. Analysis of Consumer Demand for Traceable Pork in China Based on a Real Choice Experiment. China Agric. Econ. Rev. 2015. [CrossRef]

74. Zhang, L.; Pang, J.; Chen, X.; Lu, Z. Carbon Emissions, Energy Consumption and Economic Growth: Evidence from the Agricultural Sector of China's Main Grain-Producing Areas. Sci. Total Environ. 2019, 665, 1017-1025. [CrossRef] [PubMed]

75. Chandio, A.A.; Jiang, Y.; Rehman, A. Energy Consumption and Agricultural Economic Growth in Pakistan: Is There a Nexus? Int. J. Energy Sect. Manag. 2019, 13, 597-609. [CrossRef] 